(where there has been no previous knowledge of phrenology, training, nor whispering and training during the sleep) to the law of sympathy and association, the tactical impressions exciting into action, through the reflex function of the nerves, certain combinations of muscles of expression and attitude in the head, "face, trunk, and extremities, and that then this activity of the maseles constituting the " anatomy of expression," suggests the idea to the mind with which it is ordinarily associated during the waking condition, and of which, from their extreme mobility, sympathy, and tendency to imitate, they instautly give active manifestation. This, however, can only be readily manifested, in the first instance, at one stage of sensation, but is more readily excited afterwards, as the law of double-consciousness then comes into play, and enables them to recal, as an act of memory, the idea of all which happened immediately subsequent to such itouch or stimulus on former occasions.

In conclusion: almost all which I contend for as producible by hypnotism is admitted by Dr. Hall as either "proved" or " proHable" and as the result of the reciprocal action of the mind and body of the patient upon each other, "without any new agency, whether designated mesmeric, magnetic, occult, or by any other name."

Now these embrace my most important propositions, and I cannot therefore suppose that, in the instances referred to, Dr. Hall had any intention to misrepresent my views, but that it arose from his desire to condense his matter into as narrow a compass as possible; still it was no less requisite that I should rubmit the above explanations.

I remain, Sir, your obedient servant,

St. Peter's.square, Manchester, May 19 th, 1845. JAMES Braid.

\section{THE COMMITTEE AGAIN.}

To the Editor of THE LANCET.

Srr,-I am desirous at once of adopting the suggestions contained in your journal of the 17 th inst., and recording $\mathrm{my}$ opinion and earnest wish in favour of enfranchisement in the College of :Surgeons, of which I have been a member now nearly ten years, to which I am much attached, and have hitherto (until its late proceeding) viewed it as my Alma Mater.

Though also a member of the National Association, in which I enrolled myself with the simple view of adding my testimony to that of the rest of my professional brethren, to the gross injustice of the late proceedings of the Council of the College of Surgeons, and thus by our united voice seeking to obtain by every means in our power that redress we so cogently claim at their hands; I at the same time utterly disclaim individually any wish, notwithstanding $\mathrm{my}$ present indignant feelings, to secede from my college. On the contrary, I still hope some equitable adjustment, may yet, by careful representation between-all parties, be effected with the college.

I beg to say, in conclusion, that I filled up the paper forwarded to me the other day by the committee, under the full impression that it referred to the present College of Surgeons, and not a new institution, and that the object was to convey each member's views as to the various alterations proposed with regard to the fellowship of the existing college.

I am, Sir, yours obediently,

High Wycombe, Bucks.

Wrulum Rose, Jun., M.R.C.S. \& L.A.C.

\section{MR. HAWES, M.P., AND THE LAWLESS COMMITTEE.}

To the Editor of THE LANCET.

STr,-I have responded to the appeal made to me in your last week's publication, as one of the practitioners of Lambeth.

$I$ addressed a letter to Mr. Hawes this morning wherein I stated, in the mos: unqualified terms, that if that honourable member supposed that the committee sitting in Hanover-square represented the wishes and feelings of the great bulk of the profersion, he was labouring under a very fatal error. That the majority of the general practitioners repudiated the whole of their conduct, and were favourable to enfranchisement in their own college; and that if the sense of the profession could be ascertained, it would be found that by far the greater number were averse to the formation of a separate and degraded institution.

I entreated him to avail nimself of all the forms of the House to oppose the passing of the amended Bill, and in case this should be found impracticable, to use his most strenuous endeavours to procure an amelioration of the obnoxious clauses. I hope all my professional neignbours in this borough will see the necessity of aropting a similar course; and should we ultimately fail in obtaining for ourselves that position in public estimation we are so justly entitled to occupy, at least we shall be supported by the consolatory reflection, that we struggled to the last for the main tenance of our just rights.

Your second proposition I could not respond to with similar alacrity. After the declaration publicly made by Mr. Ancell, at the last special meeting of the Association in Hanover-square, it would have been incompatible with good faith for me to have remained longer a member of that Association. I immediately, and without reserve, withdrew my name from the list, deeming it more consistent with sound principles to recede from that Association when $I$ had ceased to feel confidence in the conduct and proceedings of their self-elected and permanently constituted committee.

It would be a work of supererogation on this occasion, to offer my humble meed ot praise for your straightforward and consistent conduct, in adrocating the rights and interests of the general practitioners of this kingdom. You have devoted your splendid talents to the ad ancement of the medical profession of this country in the scale of rank and respectability; and whatever may be the result of the present struggle, you at least will deserve, and I doubt not, will ultimately receive, the grateful acknowledgments of the whole profession.

With many apologies for this intrusion on your valuable time, I remain, Sir, yours obediently,

Westminster Bridge-road, May 26th, 1815. JoHN L. I'ON.

\section{THE LAWLESS COMMITTEE.}

\author{
To the Editor of THE LANCET.
}

Srn,-I beg to enclose to you a copy of a letter I sent to the National Association, and the answer I received. If you think proper to give publicity to my letter in your valuable periodical, you are quite at liberty to do so. I hope, before long, many others will follow my example, and remain, sir,

Your most obedient servant, J. BERNCASTLE.

\section{To the Committee of the National Association of General} Practitioners.

Gentemen, - I request that you will withdraw my name from the $\mathbf{N}$ ational Association, with which I wish to disconnect myself, in consequence of my entire disapprobation of your illiberal, unjust, and impolitic conduct, in refusing to Mr. Wakley a place in the committee. Considering him, as I do, the well.tried champion of medical reform, in which he has laboured successfully for more than twenty years, I think he has a prior claim to any other member of the committee, whose untried zeal in the question is but of a day.

Mr. Wakley, by his high social position is "ipse agmen," and it is a poor specimen of the works of reformers, to begin by an act of injusice towards a man who has fought our battles alone, when no other voice was raised in our defence, and used his eloquence and his pen for a quarter of a century in our cause.

I remain, gentlemen, your most obedient servant.

Croydon, 7, May, $18 \pm 5$.

$$
\text { J. Berncastle, M.D., M.R.C.S., L.A.C. }
$$

THE NATIONAL ASSOCIATION OF GENERAT PRACTITIONERS IN MEDICINE, SURGERT, AND MIDWIFERT.

Office, 294, Regent-street, May 12, 1845.

Srr,-We are desired by the committee to acknowledge the receipt of your letter of the 9 th inst., requesting that your name be withdrawn from the National Association, and to inform you that your request has been complied with.-We have the honour to remain, Sir, your obedient servants,

J. Berncastle, Esq. M.D., \&c.

$$
\left.\begin{array}{l}
\text { J. BrRd, } \\
\text { H. Axcel, }
\end{array}\right\} \begin{array}{r}
\text { Hon. Secs., } \\
\text { pro tem. }
\end{array}
$$

\section{COMPLAINTS OF THE STUDENTS OF THE MAN-} CHESTER MEDICAL SCHOOL. To the Editor of THE LANCET.

Srn,-We wish, with your permission, to make a few remarks on the way in which the prizes were distributed at the Manchester School of Medicine and Surgery, this year; also, on the treatment of the students at the Infirmary. We will only mention the third anatomical prize, as that will illustrate the others: it was conducted by writren questions, which were to be answered in writing before leaving the school. The "successful candidate" is a Mr. J. S. Jackson, of the Royal Infirmary, (who was never accounted "clever" in his professionai acquirements by the students in general, ) who, during the crmpetition, was suspected. in consequence of having so many visitors, to be receiving answers, which in a very short time was verified, by a gentleman being caught 